NBER WORKING PAPER SERIES

\title{
INFLATION AND THE BENEFITS FROM \\ OWNER-OCCUPIED HOUSING
}

Patric H. Hendershott

Sheng Cheng Hu

Working Paper No. 383

NATIONAL BUREAU OF ECONOMIC RESEARCH 1050 Massachusetts Avenue

Cambridge MA 02138

August 1979

The research reported here is part of the NBER's research program in Financial Markets and Monetary Economics. Any opinions expressed are those of the authors and not those of the National Bureau of Economic Research. 
Inflation and the Benefits from Owner-Occupled Housing

\section{ABSTRACT}

While inflation may be public enemy one for many Americans, most homeowners have reaped enormous benefits from inflation during the past decade and a half and will likely continue to do so in the future. These benefits take two forms. First, unanticipated inflation raises the capitol gain earned at the time of sale above that anticipated at the time of purchase. The realized real after-tax return on the equity investment in the house exceeds the anticipated real. after-tax return to the extent that (1) the house purchase was financed by a mortgage and/or (2) unanticipated inflation in housing prices exceeds unanticipated general inflation. Second, the eventual increase in anticipated inflation lowers the user cost of capitol for owner-occupied housing owing to declines in real after-tax interest rates. As a result, more housing is purchased and the consumer surplus earned on housing rises. Thus homeowners first earned an extracrdinary real monetary return and then received enormous benefits in kind from occupying larger, higher quality houses. The present paper provides estimates of these for homeowners in different marginal tax brackets for different periods during the last fifteen years and draws some public policy conclusions from the sentiments.

Patric II. Hendershott and Sheng Cheng Hu Krannert Graduate School of Management Purdue University West Lafayette, Indiana 47907 $317 / 493-1884$ 
OWNER-OCCUPIED HOUSING

Patric H. Hendershott and Sheng Cheng $\mathrm{Hu}^{*}$

While inflation may be public enemy number one for a significant portion of Americans, many homeowners have reaped enormous benefits from inflation during the past decade and a half and promise to continue to do so in the future. These benefits take two forms. First, unanticipated inflation raises both the value of the implicit rents flowing from an existing house and the capital gain earned at the time of sale above those anticipated at the time of purchase. The realized real after-tax return on the equity investment in the house will exceed the anticipated real after-tax return to the extent that (1) the house purchase was financed by a mortgage and/or (2) unanticipated inflation in housing prices and rents exceeds unanticipated general inflation. Second, the eventual increase in anticipated inflation lowers the user cost of capital for owner-occupied housing owing to declines in the real after-tax cost of mortgage financing and yields on alternative financial asset investments. As a result, more housing is purchased and the consumer surplus earned on housing (the housing stock times the excess of the average product over the marginal product) rises. Thus homeowners first earn an extraordinary real monetary return and then receive enormous benefits in kind from occupying larger and higher quality houses. The present paper provides estimates of the gains from both unanticipated and anticipated inflation for homeowners in different marginal tax brackets for different periods during the last fifteen years.

* An earlier version of this paper was presented at the Mid-Year Meetings of the American Real Estate and Urban Economic Association, Washington D. C., May 23, 1979. The research is supported by the Department of Housing and Urban Development under grant H-2987. This work was stimulated by the imaginative analysis of Villani (1978) and comments by Sheridan Titman, Robert Van Order, and Kevin Villant are gratefully acknowledged. 
The first two sections of the paper pertain to the calculation of realized real rates of return on homeowner equity. A framework for making the calculations is provided in Section I, and the results are reported and interpreted in Section II. Results are given for overlapping six-year intervals between 1962 and 1978 for homeowners in the $0.15,0.3$, and 0.45 marginal tax brackets, and calculations are reported for the contributions tothe extraordinary real returns earned on a fixed-rate mortgage (relative to both no mortgage and a variable-rate mortgage) and of differences in relative inflation rates. The next two sections deal with the impact of increased anticipated inflation on the demand for housing and the consumer surpluses reaped on owner-occupied housing. The impact of increases in expected inflation on user costs of capital and consumer surpluses is examined and measured in Section III, again for overlapping six-year periods for homeowners in different tax brackets. Measures of the impact of inflation both anticipated (on realized real returns) and unanticipated (on consumer surpluses) are combined in Section IV. 


\section{The Conceptual Framework}

The after-tax rate of return on equity invested in owner-occupied housing is that discount rate which equates the present value of the after-tax net revenues from the house to the initial equity investment. The gross revenues consist of an implicit flow of net rental services over time and a lump sum at the selling date (asset price net of selling costs and the outstanding mortgage on that date). The costs include flows of mortgage and property tax payments, after allowance for their income tax deductibility. If inflation generates increases in net revenues at the quarterly rate $p$ and housing prices at rate $q$ and the house, and thus the implicit rent, deteriorate at the quarterly rate $d$, then the rate of return, $e$, would be obtained by solving present value stwo

$$
\begin{aligned}
& (1-\alpha) P_{k}=\sum_{t=1}^{N} \frac{(1+p-d)^{t-1} P_{x} p}{(1+e)^{t}}-\sum_{t=1}^{N} \frac{\left(1-\tau_{y}\right) \tau_{p}(1+q-d)^{t-I_{P}}}{(1+e)^{t}}-\sum_{t=1}^{N} \frac{P_{t}}{(1+e)^{t}}
\end{aligned}
$$

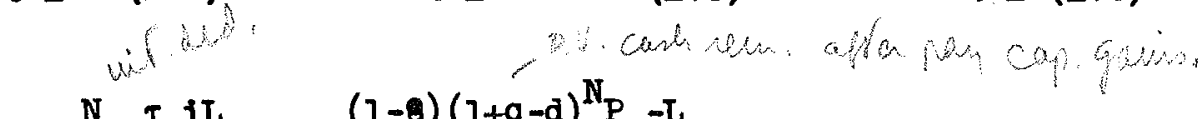

$$
\begin{aligned}
& +\sum_{t=1}^{N} \frac{T y^{I L} L_{t-1}}{(1+e)^{t}}+\frac{(1-B)(I+q-d)^{N} P_{k}-I_{N}}{(1+e)^{N}}
\end{aligned}
$$

where $I_{t}$ is the loan outstanding at time $t$

$\mathrm{P}_{\mathrm{k}}$ is the purchase price of the house

$\alpha$ is the initial loan-to-value ratio $)\left(\mathrm{L}_{0} / \mathrm{p}_{k}\right)$

${ }^{P} P^{p}$ is the implicit rent during the first quarter ( $o$ is the marginal physical product and $\mathrm{P}_{\mathrm{r}}$ is the rental price)

$p$ is the inflation rate of rents (rate of change in $P_{r}$ )

$q$ is the inflation rate of house prices) (rate of change in $P_{k}$ )

d is the depreciation rate

$\tau^{y}$ is the marginal income tax rate of the purchaser

$T_{p}$ is the property tax rate

i Is the mortgage rate 
8 is the percentage realtors fee for selling the house

$\mathrm{PAY}_{t}$ is the quarterly mortgage payment

N is the holding period

e is the after-tax return on equity.

The left-hand side equals the equity investment. The first sum on the right is the present value of the stream of implicit rents, the second sum the present value (negative) of property tax payments(allowing for their tax deductibility), the third the present value of mortgage payments, the fourth the present value of the tax saving from the interest deductions, and the last term the present value of the large sum remaining after the house is sold and the then outstanding mortgage is repaid.

When the mortgage is a standard fixed-rate, flxed-payment mortgage or when the variable-rate is expected to remain at the constant value $i$ through period $N$.

$$
\operatorname{PAY}_{t}=\operatorname{PAY}=\frac{(1+i)^{M_{1 \alpha P}} k}{(1+i)^{M}-1} \text { and } \quad L_{t}=\frac{(1+i)^{M}-(1+i)^{t}}{(1+i)^{M}-1} \alpha P_{k}
$$

where $M$ equals the original term-to-maturity (in quarters) of the mortgage. Substituting these expressions into (1.1), employing the general finite sum rule that $\sum_{t=1}^{N} \frac{(1+p-d)^{t-1}}{(1+e)^{t}}=\frac{1-(1+p-d)^{N}(1+e)^{-N}}{e-p+d}$ and solving for $p$, one obtains

$$
\begin{aligned}
& M 0 \rho \quad \rho=\left(\frac{e-p+\alpha}{\delta_{p}}\right) \frac{P_{k}}{P_{r}}\left[1-\alpha+\frac{\left(1-\tau_{y}\right) \tau_{p}^{\delta} q}{e-q+\alpha}+(1-\tau) \frac{(1+i)^{M} \alpha}{(1+i)^{M}-1}\left(\frac{1-(1+e)^{-N}}{e}\right)+\right. \\
& \frac{T_{Y}^{\alpha}}{(1+1)^{M}-1}\left(\frac{1-(2+1)^{N}(1+\infty)^{-N}}{-1}\right)+\frac{\alpha(1+1)^{M}(1+e)^{-N}}{(1+1)^{M}-1}- \\
& \left.\frac{\alpha(1+1)^{N}(1+e)^{-N}}{(1+1)^{N}-1}-(1-8)(1-8)\right]
\end{aligned}
$$

where

$$
A_{p}=1-\frac{(1+p-d)^{N}}{(1+e)^{N}} \text { and } \quad h_{q}=1-\frac{(1+q-d)^{N}}{(1+e)^{N}}
$$


When the variables on the right-hand side of equation (1.2) refer to expected, rather than realized, values, the right side is a user cost-of-capital expression for owner-occupied housing. This rather complicated user cost is the hurdle rate that the marginal physical product from additional housing investment must exceed in order for the investment to be undertaken. In equilibrium, households will have invested in housing up to the point where equation (1.2) holds. The equilibrium marginal product, then, can be computed from the depreciation and expected inflation rates: (d, $p$, and $q)$, the terms of the mortgage $(\alpha, i$, and $M)$, the property tax rate and realtor's fees ( $T_{p}$ and $\left.B\right)$, and the homeowner's expected holding period (N), income tax rate $\left(\tau_{y}\right)$, and required rate of return (e). To compute realized rates of return over a given $N$ period span for homeowners in a given tax bracket, one simply plugs in the above-calculated $\rho$ for that tax bracket, replaces $p$ and $q$ with ex post values, and solves for $e$.

The finite holding period, in conjunction with $B$ and the multiple inflation and financing rates, make (1.2) a complicated expression. A series of assumptions can transform (1.2) into relationships that better illustrate the primary determinants of $p$ and that are probably more familiar to the reader. If the required after-tax rate of return equals the after-tax mortgage rate itself, i.e., $e=\left(1-r_{y}\right) i$, then

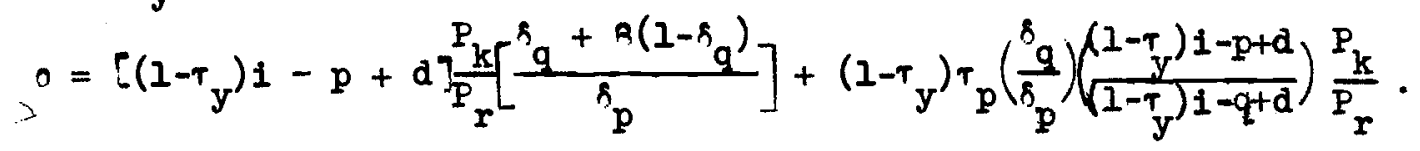

For taxpayers in low to medium marginal tax brackets this assumption seems plausible because taxable bonds/mortgages are a reasonable investment alternative. For taxpayers in higher tax-brackets, tax-exempt securities offer a superior return. It is assumed that e equals $\left(1-\tau_{y}\right) i$ for $\tau_{y} \leq 0.3$ and $0.7 i$ for $\tau_{y}>0.3$. Note that when $e=\left(1-\tau_{y}\right) i$ and thus equation $(1,3)$ holds, the equilibrium marginal product is independent of the size of the mortgage $(\alpha)$. 
Going a step further, if the housing inflation rates are equal $(p=q)$ $1 /$ and there are no selling costs $(\beta=0)$, then one obtains

$$
0=\left[\left(1-\tau_{y}\right) i-q+d+(1-\tau y) \tau p\right] \frac{P_{k}}{P_{x}} \text {. }
$$

The right side of (1.4) is a simple user cost of capital expression that reflects the current tax treatment of housing (no taxation of implicit rents and the deductibility of property taxes and mortgage interest) and of interest income (taxation at rate $\tau_{y}$ ). While these simplifications aid in understanding the factors involved, equation (1.2) will be employed in the calculations.

\section{Realized Extraordinary Real Rates of Return}

\section{A. Inflation Rates and Other Data}

There are two housing prices series in the model: the price of implicit rents (the rent component of the consumer price index) and the price of houses (the NIA deflator for residential structures). In order to compute real rates of return, a third series is needed. The NIA aggregate-private deflator is employed for the general inflation index. The ex post (denoted by bars over the symbol) inflation rates are listed in Section $A$ of Table 1 for these series by three year intervals over the 1961-78 period. The general rise in inflation since the early $1960 \mathrm{~s}$ is obvious in all three series. The rental series rose slightly less rapidly than the general price index during

It is also assumed that $\mathrm{q}-\mathrm{d}<\mathrm{e}$.

26wing to an absence of data on land prices, the present analysis considers investment in structures only. If land prices are perfectly correlated with structures prices, then the analysis is unaffected. If inflation in land prices were to exceed inflation in structures prices [see von Furstenberg (1977, pp. 281-88)], then the calculations presented below understate the excess real returns earned on equity in homeownership. 
Table 1: Inflation Pates (\% per annum)

A. Bx Post Inflation Rates

$\begin{array}{lllll}1961-63 & 1964-66 & 1967-69 & 1970-72 \quad 1973-75 \quad 1976-78\end{array}$

\begin{tabular}{|c|c|c|c|c|c|c|}
\hline General $(\bar{y})$ & 0.88 & 2.42 & 4.39 & 3.52 & 8.30 & 6.19 \\
\hline 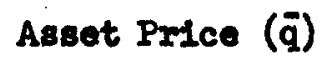 & -0.39 & 2.33 & 5.68 & 4.57 & 9.09 & 10.16 \\
\hline 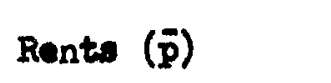 & 1.08 & 1.22 & 2.86 & 3.93 & 4.94 & 6.08 \\
\hline
\end{tabular}

B. Bxpectod Inflation Rates

$\begin{array}{lllllll} & 1964 & 1967 & 1970 & 1973 & 1976 & 1979 \\ \text { GeneraI (y) } & 1.24 & 1.65 & 3.40 & 3.95 & 5.88 & 7.24 \\ \text { Asset Price (q) } & -0.13 & 0.96 & 3.99 & 5.12 & 6.80 & 9.63 \\ \text { Rents (p) } & 1.31 & 1.15 & 1.95 & 3.30 & 4.43 & 5.51\end{array}$

a/The date refer to the fourth quarter of the preceding year and are calculated as geometric averages of ex post inflation rate during the previous 24 quarters.

C. Unanticipated Inflation Rates

$\begin{array}{lccccc} & 1964-69 & 1967-72 & 1970-75 & 1973-78 & 1965-78 \\ \text { General }(\bar{y}-y) & 2.16 & 2.30 & 2.48 & 3.29 & 3.57 \\ \text { Asset Pr1ce }(\bar{q}-q) & 4.12 & 4.16 & 2.81 & 4.51 & 6.44 \\ \text { Rents }(\bar{p}-p) & 0.64 & 2.15 & 2.48 & 2.21 & 2.75\end{array}$


1964-69, and much less rapidly in 1973-75; the house price series increased at a slightly lower rate in 1961-63, slightly more rapid rate in 1967-75, and by 4 percentage points per annum more during the last three years.

The expected inflation rate at any point in time is measured as a geometric average of the ex post inflation rates during the previous 24 quarters. ${ }^{3 /}$ Estimates at the beginning of various years are provided in Section B of Table 1 for a.1 three inflation rates. Not surprisingly, all series increase almost continuously. Unanticipated inflation during a period is defined as the difference between the observed inflation rate during the period and the rate expected at the beginning of the period. Given the measurement of expected inflation, unanticipated inflation during a six-year period is the expected inflation rate at the end of the interval (the observed rate during the period) less the expected inflation rate at the beginning of the interval. To illustrate, unanticipated general inflation for the 1973-78 period ( 3.29 percent) is the expected inflation rate at the beginning of 1979 (7.24 percent) less the expected rate at the beginning of 1973 ( 3.95 percent). Estimates of unanticipated inflation over overlapping six year periods and for the entire 1965-78 period are presented in Section C. Unanticipated general inflation rises slightly over time from 2 percent in $1964-69$ to over 3 percent in 1973-78; unanticipated inflation in house prices is always higher, although it declines to under 3 percent in the 1970-75 period; and unanticipated inflation in

3/Expected inflation rates based upon actual rates during the previous 12 quarters are reported in an appendix. Other candidates for expected inflation are the Treasury bill rate less a constant and the Livingston survey data on expected inflation. These series are not employed because they are proxies for expected inflation over a very short time horizon. 
rents between 1967 and 1978 is $\frac{1}{2}$ to $1 \frac{1}{4}$ percent less than unanticipated general inflation. Unanticipated inflation over the longer 1965-78 period is higher than for the subperiods owing to the low expected inflation rates at the end of 1964 $(y=1.54, q=0.19$ and $p=1.21$ ).

The other data employed in the rate-of-return calculation can be described briefly. The annual depreciation and property tax rates are assumed to be 0.02 and 0.018 , respectively, and realtor's fees (B) are set at 6 percent of the value of the house. The house purchase is assumed to be 75 percent financed with a 25-year, fixed-rate mortgage. The mortgage yield series utilized is the FHLB's effective rate series for the 1963-72 period and the FHLB's effective rate on 75\%-25 year new home comitments for the 1973-78 period [EHLB Journail, June 1978 ]. Rates of return are calculated for households in the $0.15,0.3$ and 0.45 marginal tax brackets. As noted above, the required after-tax rates of return on housing equity are assumed to be 0.85 times the mortgage rate for those in the 0.15 tax bracket and 0.7 times the mortgage rate for those in the 0.3 and 0.45 tax brackets.

\section{B. Excess Nominal and Real Returns}

Households are assumed to invest in housing up to the point that the return on the last dollar invested yields a marginal product such that the expected return over the homeowner's holding period equals the required return or that available on alternative investments. Following the procedure described in Section I, equation (1.2) is first solved for $\phi$, where e is the required aftertax rate of return and $p$ and $q$ are expected inflation rates, and then resolved

\footnotetext{
4 For an analysis explaining relative changes in housing and rental prices, see Titman (1979).
} 
for the ex post return, $\vec{e}$, based upon the calcula ted o and ex post inflation rates $\vec{p}$ and $\vec{q}$. The extraordinary nominal returns, $\bar{e}-e$, are then computed. These are reported in the top section of Table 2 for the same four overlapping 6-year periods and longer 14-year interval featured in Table 1.

Two facts are obvious. First, the extraordinary returns earned on owneroccupied housing have been enormous over the past decade and a half. The excess returns have ranged from about 8 percent per year in the "worst" 1970-75 period, when unanticipated inflation in house prices was relatively low, to over 10 percent in three of the five periods. In general, housing has earned a 10 percentage point return above that available on investments in financial assets. This is, of course, a direct result of unanticipated inflation and the leveraged investment in the real housing asset. Second, the excess returns are largely independent of the tax bracket or income level of the investor. While higher tax bracket investors have earned greater returns in most periods, the difference in the excess returns is small.

While the data in the top section of Table 2 demonstrate that households earned substantial excess returns on housing relative to those available on financial assets, one might ask whether homeowners were better off in a real sense. This is equivalent to asking whether excess real returns were earned on housing, and the question can be answered by subtracting unanticipated general inflation (the first row in Section C, Table 1) fram the excess nominal returns. This subtraction has been performed in the lower section of Table 2 . The ex post real return on owner-occupied housing $(\bar{e}-\bar{y})$ has exceeded the expected real return (e-y) by 5 to $8 \frac{1}{2}$ percent per annum over various subintervals of the 1964-78 period.

$5 /$ Results when the expected inflation rates are based upon ex post rates during the previous 12 quarters are reported in an appendix. Bxtraordinary real returns, under this assumption, vary between 3 and 9 percent per annum. 
Table 2: Bxtraordinary Nominal and Real Returns Earned on Invertmant

\section{In Owner-Occupied Houleing (\%)}

Bxcess Nominal

Returns ${ }^{\top} y \quad 1964-69$ 1967-72 1970-75 1973-78 1965-78

$\begin{array}{lllllll}(1) & 0.15 & 9.76 & 10.45 & 7.85 & 10.27 & 8.44 \\ (2) & 0.30 & 10.32 & 10.75 & 7.83 & 10.61 & 9.16 \\ (3) & 0.45 & 10.60 & 10.79 & 7.70 & 10.73 & 9.48\end{array}$

\section{\begin{tabular}{c} 
Excess Real \\
Roturns \\
\hline
\end{tabular}}

$\begin{array}{lllllll}(4) & 0.15 & 7.60 & 8.15 & 5.37 & 6.98 & 4.87 \\ (5) & 0.30 & 8.16 & 8.45 & 5.35 & 7.32 & 5.59 \\ \text { (6) } & 0.45 & 8.44 & 8.49 & 5.22 & 7.44 & 5.91\end{array}$

a/ Fxcess nominal returns less unanticipated general inflation $(\bar{y}-y)$. 
It should be emphasized that these are spendable real gains. Young, growing families have often used the gains to purchase additional housing. Older shrinking families often realize some gains when moving to a smaller unit, and, with the new reverse mortgages, can borrow automatically against the gains. Often households implicitly realize the gains by borrowing (second-mortgages or consumer credit) or by reducing their savings out of current income.

C. Sources of Differences in Bx Post and Expected Real Returns There are two primary sources of differences between ex post and ex ante real returns: differences in relative unanticipated inflation rates and the existence of mortgage debt. To see the importance of the former, consider equation (1.4) when $\alpha=0$. Replacing (1-T $)_{y}$ i with $e$, solving for $e$, and subtracting the expected general inflation rate $y$ from both sides, the expected real rate of return on housing equity is

$$
e-y=\frac{P_{r}}{P_{k}}-d-\left(1-\tau_{y}\right) \tau_{p}+q-y .
$$

The ex post equivalent is

$$
\bar{e}-\bar{y}=\frac{P_{r^{0}}}{P_{k}}-d-\left(1-\tau{ }_{y}\right) \tau_{p}+\bar{q}-\bar{y},
$$

where bars over variables denote ex post values. Subtracting (2.1) from (2.2) and solving

$$
\bar{e}-\bar{y}-(e-y)=\bar{q}-q-(\bar{y}-y) .
$$

Thus, with $\alpha=0, p=q$ and $\beta=0$, ex post and ex ante real returns on housing equity would vary one-for-one with differences in unanticipated inflation rates.

To illustrate the importance of mortgage debt, consider the one-period version of $(1.2)$ when $\beta=0$ and $p=q$ : 


$$
\frac{P_{x}^{0}}{P_{k}}=(1-\alpha) e+\left(1-\tau_{y}\right) \alpha 1-q+d+\left(1-\tau_{y}\right) \tau_{p}
$$

which can be rewritten as

$$
(1-\alpha)(e-q)=\frac{P_{r}^{p}}{P_{k}}-\alpha-\left(1-\tau_{y}\right) \tau_{p}-\alpha\left[\left(1-\tau_{y}\right) 1-q\right] .
$$

The ex post equivalent, assuming a fixed-rate mortgage, is

$$
(1-\alpha)(\bar{e}-\bar{q})=\frac{P_{p} \rho}{P_{k}}-\alpha-\left(1-\tau_{y}\right) \tau_{p}-\alpha\left[\left(1-\tau_{y}\right) i-\bar{q}\right] .
$$

Subtracting (2.3) from (2.4) and solving

$$
\vec{e}-\bar{q}-(e-q)=\frac{\alpha}{1-\alpha}(\bar{q}-q)
$$

With no difference in unanticipated inflation rates $(\bar{q}-q=\bar{y}-y)$, the ex post real return on equity will devlate from the expected real return by a multiple $[\alpha /(1-\alpha)]$ of unanticipated inflation.

The existence of a mortgage w1ll not necesserily result in extreordinary gains when unanticipated inflation rates are positive (and equal). Assume that the mortgage has a variable rate $\hat{i}$. With $\bar{q}-q=\bar{y}-y$, subtraction of (2.3) from (2.4), after replacing $i$ in (2.4) with 1 , ylelds

$$
\bar{e}-\bar{y}-(e-y)=-\frac{\alpha}{1-\alpha} \cdot\left[\left(1-\tau_{y}\right)(1-i)-(\bar{y}-y)\right] \text {. }
$$

With $I=1+(\bar{y}-y) /\left(1-\tau_{y}\right)$, extraordinary reel returns would necesearily be zero. That is, if the index rate of the variable-rate mortgage moved with a multiple $\left[1 /\left(1-T_{y}\right)\right]$ of unanticipated inflation, such that the realized real after-tax variable rate equalied the initial rate, then the mortgage vould 
not provide extraordinary returns during periods of unanticipated inflation. of course, no known index rate rises this rapidly because (1) interest rates move with expected inflation which tends to adjust gradually to unanticipated inflation and (2) the movement tends to be only one-for-one, rather than a multiple. 6/

The contributions of the mortgage and relative unanticipated inflation rates to the excess ex post returns earned on housing over selected six-year periods are listed in Table 3. The first row simply reproduces row (5) of Table 2, except that data for the 1962-67 interval have been added in order to include a period where excess housing gains were relatively minor. As is indicated in row (2), most of the excess return is due to the existence of a mortgage during a period of unanticipated inflation. The contribution of the mortgage moves directly with unanticipated housing inflation, which rose in the late 1960 s declined in the early 1970s, and rose again in the middle 1970s (see Table 1). Because unantici: pated housing inflation exceeded unanticipated general inflation in every period [see row (4)], relative unanticipated inflation always made a positive contribution to the excess real ex post return on housing. However, the contribution never exceeded $1 \frac{1}{1_{4}}$ percentage points. Comparison of rows (2) and (4) suggest that a percentage point excess of unanticipated housing inflation over general inflation raises the ex post real return by about half of a percentage point.

It is sometimes argued that the existence of variable-rate mortgage (VRMs) would be "unfair" to existing homeowners during periods of unanticipated

$6 /$ Feldstein (1976, p. 816 , note 15) argues that the failure of interest rates to move with a multiple of expected inflation is due to the taxation of nominal capital gains and the use of historic-cost depreciation. Hendershott (1979) provides analysis to support this conjecture. For an analysis emphasizing non-tax factors that might account for interest rates not rising with a multiple of expected inflation, see Levi and Markin (1978). 
Table 3: Sources of Extraordinary Real Returns for Different Six Year Holding Periods, ${ }^{\top} y=0.3(\%)$

Excess for Post Real Returns

(1) Owing to Mortgage

(2) Owing to Relative Inflation

$\begin{array}{ccccc}\frac{62-67}{2.23} & \frac{64-69}{8.16} & \frac{67-72}{8.45} & \frac{70-75}{5.35} & \frac{73-78}{7.32} \\ 1.88 & 7.24 & 7.36 & 5.20 & 6.52 \\ 0.35 & 0.92 & 1.09 & 0.15 & 0.80\end{array}$

Memorandrum

(3) Reduction in Post Real Rate if VRM Existed a/

0.84

1.24

$-0.16$

1.28

(4) Excess of Unanticipated Housing Inflation over General Inflation b/

$0.59 \quad 1.96$

1.86

0.33

1.38

a/Assumes index rate is new issue home mortgage rate.

$\mathfrak{b} / \bar{q}-q-(\bar{y}-y)$ 
inflation because mortgage interest payments would rise unexpectedly. IV The existence of VRMs during such periods would obviously reduce ex post returns on the equity of existing homeowners. However, if the unexpected added interest expense is accompanied by greater unexpected real capital gains, then homeowners would still be better off in the sense that their realized real return on the housing investment would exceed their expected real return. To address this issue, realized real rates of return were calculated on the assumption that VRMs with an index rate equal to that on newly-issued fixed-rate mortgages existed. The difference between ex post returns with fixed-rate mortgages and with VRMs are listed in row (3). As can be seen, the reduction in return owing to a VRM is only a fraction of the total excess ex post return attributable to the mortgage. In no six-year period would a VRM have offset as much as one-quarter of the excess real return earned. Even with VRMs, homeowners would have earned substantial excess real returns during these periods of unanticipated inflation.

III. Bxpected Inflation, the User Cost of Capital, and the Demand for OwnerOccupied Housing

Housing economists appear to have turned 180 degrees in the past few years in their views regarding the impact of inflation on housing demand. In the early 1970 s the impact of inflation on monthly payments (and downpayments to a lesser degree) was the focus of attention. Owing to the widespread use of the fixed-payment

$7 /$ A related argument against VRMs is that households cannot manage the higher cash flow outlays. For a critique of this argument, see Hendershott and Villani (1978, pp. 17-24 and 88-90). To the extent that higher outlays do constrain household expenditures during periods in which inflation and interest rates are rising, VRMs play a useful macroeconomic stabilization role [von Furstenberg (1977, pp. 293-95) 7 . 
mortgage, inflation "tilted" real monthly payments upward during the early years of the mortgage, resulting in a sharp increase in the ratio of the initial monthly payment to current income. As a consequence, housing was "unaffordable" to those who would have been able to purchase houses or more housing in the absence 8/

of the tilt. The graduated-payment mortgage was advocated as a means af reversing this tilt, and the Emergency Home Purchase Assistance Act of 1974 was passed in which mortgage credit was to be made available at below-market interest rates when inflationary conditions were having a severely disproportionate negative effect on the housing industry.

In recent years attention has shifted to the impact of inflation on the underlying equilibrium demand for housing. The unaffordability argument pertains to a perceived disequilibrium where inflation-induced financial constraints hold effective housing demand below the equilibrium level. The underlying equilibrium demand for housing is stimulated by inflation because the real after-tax return from nonhousing investments and the cost of home mortgage credit decline. Recent (1976-78) levels of single family housing sales and production and increases in housing prices suggest that the positive impact of inflation on the underlying equilibrium demand for housing has outweighed the negative impact created by financial constraints. This would not be surprising because the financial constraints probably bind only on potential first-time home buyers who have not already reaped extraordinary housing capital gains that would allow large downpayments and thus relatively small monthly payments. In contrast,

8/See Hendershott and Villani (1978, pp. 17-24) for a brief discussion of this argument. The most thorough treatment in this area is Modigliani and Lessard (1975).

2/See Villani (1978) and (1979), Diamond (1979) and Titman (1979). 
the stimulation to equilibrium demand applies to both existing homeowners and potential first-time buyers. In this section the impact of increases in anticipated inflation on the user cost of capital and thus the equilibrium demand for housing is analyzed.

\section{A. Graphical Illustration}

In equilibrium all households will have purchased owner-occupied housing up to the point that the percentage implicit rental income earned on the last dollar of housing equals the user cost of capital as defined by the right-hand side of equation (1.2). A decline in the user cost of capital would lead households to demand additional or higher quality bedrooms, bathrooms, and family rooms until the utility or implicit rents from these decline to the lower cost of capital. The relation between the implicit rents earned by a representative household in the 15 percent tax bracket and the stock of housing occupied is denoted by the schedule labelled 0 in the left panel of Figure 1. Given the current inflation rate $q_{0}$, the cost of capital is $c_{0}$ and the quantity of housing demanded is $K_{0}$. The $p$ schedule and $c_{0}$ and $K_{0}$ values in the right panel are those relevant to a representative homeowner in the 30 percent tax bracket. The figure is drawn so that the cost of capital is lower for the homeowner in the higher tax bracket. This is true because the net (after-tax) property tax, mortgage interest rate, and opportunity cost of funds are all lower for a homeowner in a higher tax bracket. $10 /$ The importance of the tax bracket to the cost of capital is illustrated most clearly by the simple cost of capital expression on the right side of equation (1.4).

10/ For discussions of the distribution of the tax subsidy by income class, see Aaron (1972), Laidler (1969), and White and White (1977). 
FIGURE 1: THE IMPACT OF AN INCREASE IN INFLATION ON HOUSING DEMAND AND CONSUMER SURPLUS

Household with $T=0.15$

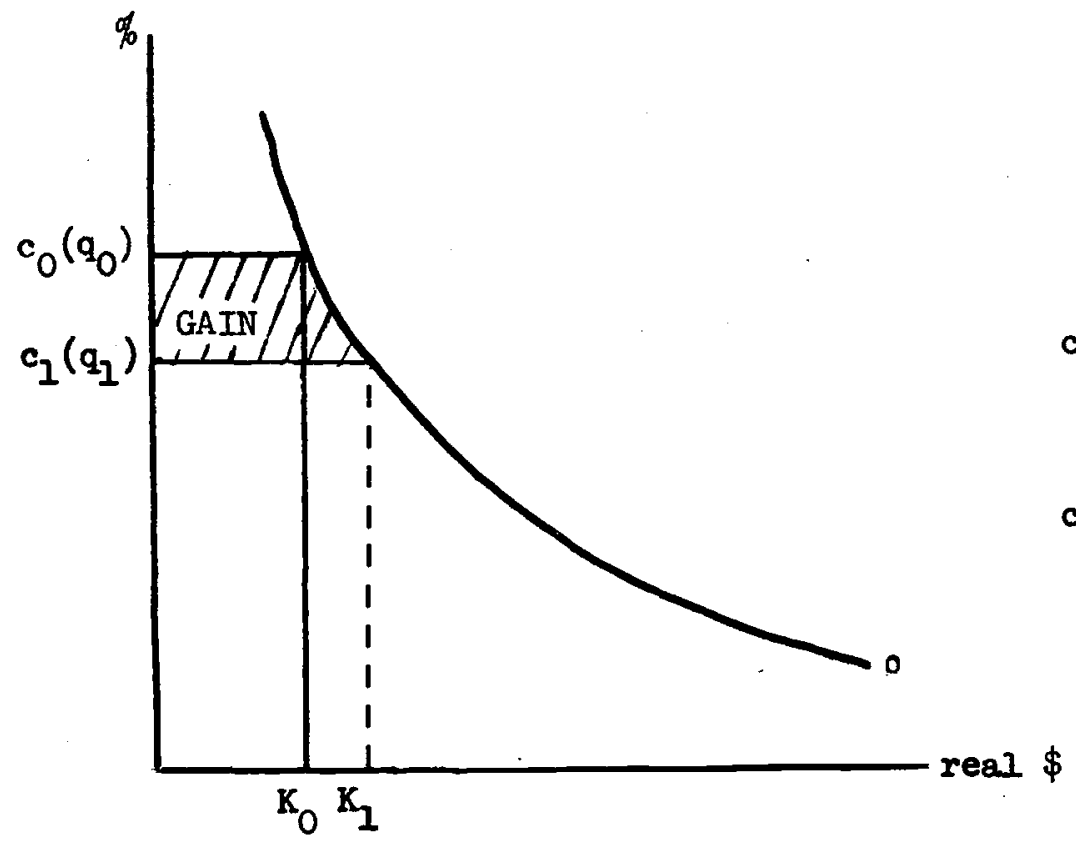

Household with $\tau=0.3$

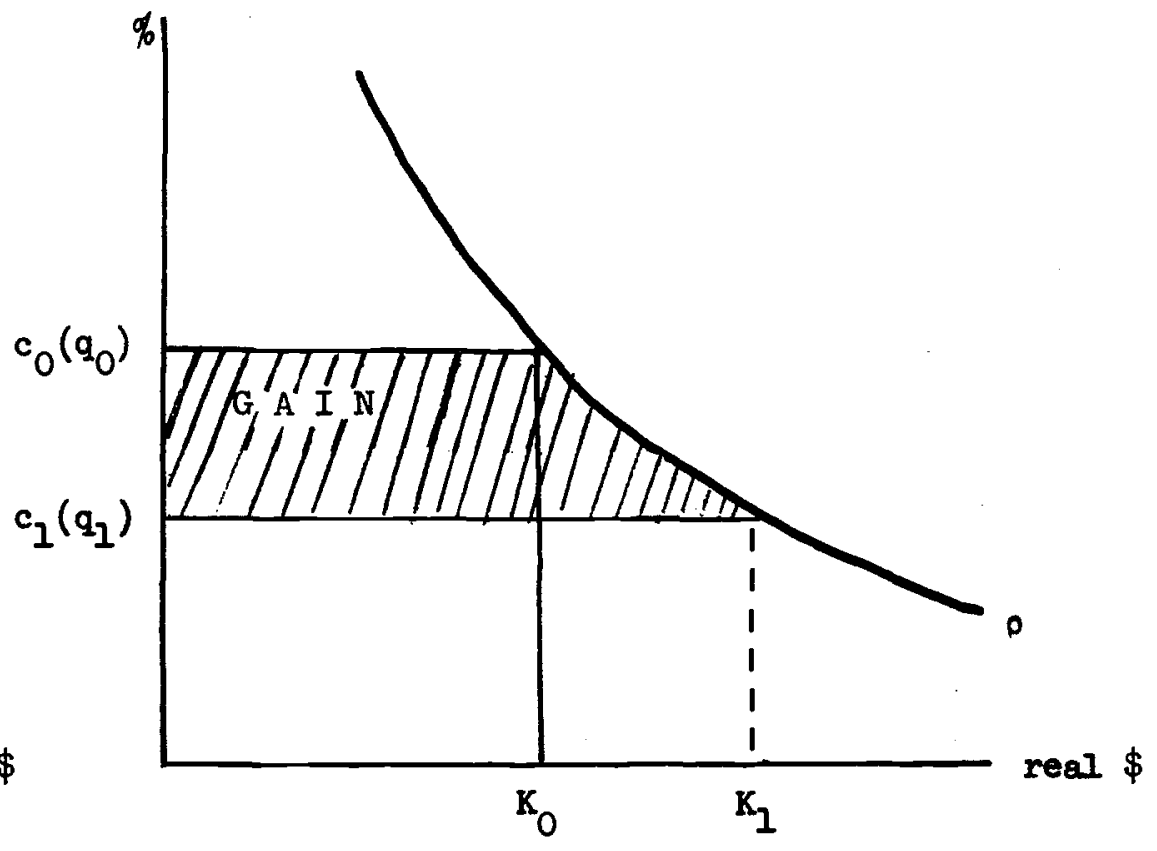


To determine the approximate impact of an increase in expected inflation on the cost of capital, we take the derivative of (1.4) with respect to $q$ :

$$
\frac{d c}{d q}=\left(1-\tau_{y}\right) \frac{\partial i}{\partial q}-1 \text {. }
$$

Thus the cost of capital will decline if $\partial I / \partial q<y /(1-\tau y)$. This inequality has held in recent years for two reasons. First, the interest rate has increased only about one-for-one with increases in the anticipated general inflation rate. Second, the anticipated inflation rate of housing prices has increased by more than has the anticipated general inflation rate (see Table 2). The impact of an increase in the expected inflation rate and the resultant decline in the user cost on the quantity of housing demanded by the two representative households is indicated by the increases from $K_{0}$ to $K_{1}$ in Figure 1. The increases in the consumer surpluses earned on housing are indicated by the hatched areas labelled GAIN.

B. User Costs of Capital and the Efficient Allocation of Resources User costs of capital for 24 and 56 quarter holding periods are reported in Table 4 for homebuyers in the $0.15,0.3$ and 0.45 marginal tax brackets at three different points in time. The first, 1964-4, is shortly prior to the acceleration in inflation; the third, 1978-3, is the most recent quarter with available data and is the quarter of peak expected inflation (to date); during the interim quarter, 1972-4, expected inflation equalled about an everage of the 1964-4 and 1978-3 values. The two noteworthy characteristics of the data are expected. First, the user costs or investment hurdle rates are lower the higher the tax bracket. Second, the hurdle rates have generally declined over

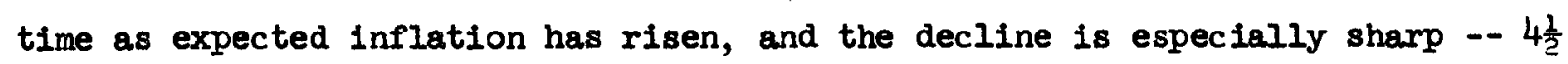
percentage points -- for investors in the 0.45 tax bracket. Moreover, this user cost of capital for these investors is slightly overstated. 
Table 4: User Costs of Capital (\%)

\begin{tabular}{lll}
\cline { 2 - 2 } & \multicolumn{2}{c}{$1964-4$} \\
$T=0.15$ & 13.33 & 12.38 \\
$T=0.3$ & 11.44 & 10.54 \\
$T=0.45$ & 9.76 & 8.93
\end{tabular}

\begin{tabular}{cc}
\multicolumn{2}{c}{$1972-4$} \\
\hline$N=24$ & $N=56$ \\
12.51 & 12.58 \\
9.88 & 9.80 \\
7.67 & 7.61
\end{tabular}

$\begin{array}{cc}\frac{2}{2} 1978-3 \\ N=24 & N=56 \\ 12.71 & 14.38 \\ 8.59 & 9.61 \\ 5.38 & 6.30\end{array}$


corporate investment in structures Hendershott and $\mathrm{Hu}(1980)$ ]. The productivity gains from reducing the tax subsidy to owner-occupied housing are thus likely to be substantial. $12 /$

IV. The Combined Benefits from Anticipated and Unanticipated Inflation

Estimates of the extraordinary realized real returns earned on investment in owner-occupied housing owing to unanticipated inflation were reported in Table 2. Our final task is to compute comparable estimates of the gains in consumer surplus generated by increases in anticipated inflation. A rough measure of the gain in consumer surpluses (the hatched GAIN in Figure 1) can be obtained by assuming that the implicit-rents curve exhibits unitary elasticity with respect to $K$. That is

$$
p=\frac{Q(Y)}{K}
$$

where $a(Y)$ is the shift factor and is assumed to be increasing with respect to income. Using the equilibrium condition $\rho=c$, the desired level of the housing stock is

$$
K=\frac{a(Y)}{c}
$$

The gain from the increase in inflation can be obtained by integrating equation (4.1) from $c_{0}$ to $c_{1}$, which yields

$$
\operatorname{GAIN}(Y)=a(Y)\left(\log c_{0}-\log c_{1}\right) \text {. }
$$

To make the consumer surplus gain in a given period comparable to the real gain on equity owing to unanticipated inflation, the gain is divided by the equity in the newly purchased house, $(1-\alpha) \mathrm{K}_{1}$ :

12/Rosen (1979) estimates a productivity gain from eliminating the housing tax subsidy of \$107 per family based upon his 1970 sample. Given that there were 40 million owner-occupied units in 1970, the total productivity gain would be roughly $\$ 4 \frac{1}{4}$ billion ( $\$ 107$ times 40 million).

$13 /$ The gain in consumer surplus is, of course, independent of the form of the financing of the housing purchase (the value of $\alpha$ ). 


$$
\frac{\operatorname{GAIN}(Y)}{(1-\alpha) \mathrm{K}_{1}}=\frac{1}{1-\alpha}\left(\log c_{0}-\log c_{1}\right) c_{1}
$$

This percentage gain can thus be obtained directly from measures of $c$ at various points in time.

The following senario underlies the calculations in Table 5. Households purchased homes in 1964-4 that provided them with the optimal quantity of housing. The decline in the user cost of capital, which was particularly dramatic after 1970, caused the households to purchase larger houses in 1972-4. These houses were held until 1978-3 when the further fall in cost of capital, which was especially rapid after 1975, induced the purchase of even larger houses. The extraordinary real gains from inflation, both anticipated and unanticipated, from 1964-4 to 1972-4 are limited to the real gain on equity investment upon the assumed sale in 1972-4. Between 1972-4 and 1978-3 further gains on equity investment were also realized, and these were supplemented by enlarged consumer surpluses owing to the lower cost of capital in 1972-4. All of these gains accrue to firsthome buyers in 1972-4, as well as households rolling into larger houses at that time. Unexpected real gains (or losses) after 1978-3 on the equity invested in the 1978-3 purchase are at this point unknown, but substantially larger consumer surpluses vis-a-vis those which would have been earned on a house purchased at the cost of capital existing in 1964-4 are known.

The annual real excess returns owing to inflation are 8 to $8 \frac{1}{2}$ percent In the 1965-72 period owing solely to unanticipated inflation (Table 5). Between 1973 and 1978 the excess real returns were 10 to 15 percent, consisting of 7 to $7 \frac{1}{2}$ percent from unanticipated inflation and 3 to $7 \frac{1}{2}$ percent from anticipated inflation. The latter excess returns increase with the income of the household. For the post-1978 period, the real excess returns range from $2 \frac{1}{2}$ to 13 percent and increase sharply with the income level. These are, of course, independent of any 
Table 5: Combined Annual Real Gains on Owner-Occupied Housing from Anticipated and Unanticipated Inflation (as a Percentage of Equity Invested at the Beginning of the Indicated Period).

\begin{tabular}{|c|c|c|c|c|}
\hline & & $1965-72$ & $1973-78$ & $1979-?$ \\
\hline \multirow{3}{*}{$T=0.15$} & Real Return on Equity Investment & 7.87 & 6.98 & $?$ \\
\hline & Added Consumer Surplus & $=-\cdots$ & 3.18 & 2.43 \\
\hline & TOTAI & 7.87 & 10.16 & $2.43+?$ \\
\hline \multirow{3}{*}{$T=0.3$} & Real Return on Equity Investment & 8.30 & $7 \cdot 32$ & $?$ \\
\hline & Added Consumer Surplus & $=-\cdots$ & 5.82 & 2.87 \\
\hline & TOTAL & $8 \cdot 30$ & $13 \cdot 14$ & $9.87+?$ \\
\hline \multirow{3}{*}{$T=0.45$} & 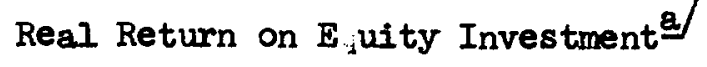 & 8.46 & 7.44 & $?$ \\
\hline & Added Consumer Surplus & $=-\cdots$ & 7.40 & 12.82 \\
\hline & TOTAL & 8.46 & 14.84 & $12.82+?$ \\
\hline
\end{tabular}

\footnotetext{
a/ Table 2 for $N=24$, 1965-72 data are averages of data for 1964-69 and 1967-72.

b/Table 5 for $\mathrm{N}=24$.
} 
future unanticipated inflation. Relative to their counterparts in late 1964, current homeowners are in an enviable position. Even if future inflation should equal anticipated inflation, todays homeowners in tax brackets of about 25 percent or higher will fare better because of their enormous consumer surpluses than the homeowners of 1964 did as a result of unanticipated inflation.

A final consideration is why, when both existing and new homeowners gained so enormously from the inflation of the past decade and a half, there is such a concern over the "rising cost of homeownership"? A plausible answer is the above-mentioned increase in financial constraints that hold effective housing demand below the equilibrium level. The movement to lower percentage downpayments and the use of graduated-payment mortgages has, of course, mitigated the impact of these constraints. Regrettably, however, much of the concern about the cost of homeownership seems to be based upon a misrepresentation of the financial costs of housing. Rather than measuring these costs in real after-tax terms, nominal before-tax costs have been employed. 14/ For example, the mortgage-interest component of the consumer price index, which is calculated as the product of a before-tax nominal mortgage rate and a house price series, rose by 39 percent between the end of 1974 and the end of 1978 . In contrast, a component based upon a real after-tax interest rate would have about halved, owing to a decline in the real after-tax $\left(\tau_{y}=0.25\right)$ mortgage rate from 2 percent to about $\frac{1}{2}$ percent. $15 /$

14/Downs (1978), in an otherwise enlightened analysis, promulgates this error. Diamond (1979) shows the true decline in the cost of home ownership.

15/The implications of this difference for movements in the CPI are being investigated by Robert Van Order and others at HUD. 
v. Summary

Unanticipated inflation results in capital gains that accrue entirely to the homeowner (unless a variable-rate mortgage exists). Thus a homeowner with a leveraged investment earns real, as well as nominal, gains, and these are especially large if housing prices rise more rapidly than prices generally. For houses held for various six-year intervals between 1964 and 1978 real annual rates of return exceeded expected real returns by 5 to $8 \frac{1}{2}$ percentage points. The existence of variable-rate mortgages (VRMB) with an index rate equal to the current mortgage rate would have lowered these excess real returns only slightly to the 5 to 7 percentage point range. Even with VRMs, unanticipated inflation benefits homeowners substantially.

Anticipated inflation lowers the user cost of capital for owner-occupied housing, the reduction being greater the higher the tax bracket of the investor, and raises the demand for housing. At late 1978 expected inflation rates, the user cost of capital, and thus the equilibrium marginal physical product of owner-occupled housing, for those in high tax brackets is only 5 percent. Given that the equilibrium marginal physical product of corporate investment in structures is about 15 percent, the favored tax treatment of owner-occupied housing is the source of significant productivity losses for the economy. Substitution of a 15 percent tax credit for the mortgage interest and property tax deductions (and cessation of the double taxation of corporate income) would lead to a considerably more efficient allocation of the American capital stock.

The fall in the cost of capital generated by increased anticipated inflation increases the consumer surpluses of homebuyers. Again, the increase is greater the higher is the homeowner's tax bracket. The gains in consumer surpluses between 1964 and 1978 for homeowners in tax brackets of 25 percent or higher, expressed as a portion of the equity invested in a 1978 house (assuming a loan-to-value ratio of $0.75)$, were even greater than the extraordinary real returns realized on housing 
equity during the 1964-78 period. Not taking the declines in user cost into account in the calculation of the mortgage interest component of the consumer price index has resulted in an overstatement of inflation during the last four years.

\section{References}

Aaron, Henry J., Shelter and Subsidies: Who Benefits from Federal Housing Policies?, Brookings Institution, 1974.

Diamond, Douglas B, Jr., "A Note on Inflation and Relative Tenure Prices," AREUEA Journal, Winter 1978.

Diamond, Douglas B., Jr., "Texes, Inflation, Speculation, and the Cost of Homeownership: 1963-78," presented at the Mid-Year Meetings of AREUEA, May 23, 1979.

Downs, Anthony, "Public Policy and the Rising Cost of Housing," Real Estate Review, Spring 1978.

Feldstein, Martin. "Inflation, Income Taxes, and the Rate of Interest: A Theoretical Analysis," American Economic Review, December 1976.

von Furstenberg, George, "The Impact of Government Housing and Credit Programs on the Cost of Housing," The Cost of Housing, Federal Home Loan Bank of San Francisco, 1977.

Hendershott, Patric H., "The Decline in Aggregate Share Values: Inflation and Taxation of the Returns from Equities and Owner-Occupied Housing," NBER Working Paper, July 1979.

Hendershott, Patric H. and Sheng-Cheng Hu, "Government-Induced Biases in the Allocation of the Stock of Fixed Capital in the United States," in G.M. von Furstenberg (ed.), Capital Efficiency and Growth, Ballinger Publishing Co., 1980.

Hendershott, Patric H., and Kevin E, Villani, Regulation and Reform of the Housing Finance System, American Enterprise Institute for Public Policy, 1978.

Ialdler, David, "Income Tax Incentives for Owner-Occupied Housing," in A. C. Harberger and M. J. Bailey (eds.), The Taxation of Income from Capital, Brookings Institution, 1969.

Levi, Maurice D. and John H. Makin, "Anticipated Inflation and Interest Rates: Further Interpretation of Findings on the Fisher Equation, "American Economic Review, December 1978. 
Modigliani. Franco and Donald Lessard (eds.), New Mortgage Designs for Stable Housing in an Inflationary Environment, Federal Reserve Bank of Boston Conference Series, No. 14, 1975.

Rosen, Harvey S., "Housing Decisions and the U.S. Income Tax," Journal of Public Economics, 11, 1979.

Titman, Sheridan D., "The Effect of Anticipated Inflation on Housing Market Equilibrium," Working Paper, Carnegie-Mellon University, March 1979.

Villani, Kevin, "The Impact of Anticipated and Unanticipated Inflation on House Prices and the Return on Home Ownership," paper presented at AREUEA Sixth Annuel Midyear Meeting, May 23-24, 1978.

Vijlani, Kevin, "The Tax Subsidy to Housing in an Inflationary Environment: Implications for After-tax Housing Costs," Office of Economic Affairs, HUD, Working Paper, March 1979.

White, Michelle and Larry White, "The Tax Subsidy to Owner-Occupied Housing: Who Benefits?" Journal of Public Economics, February 1977. 


\section{Appendix}

This appendix provides alternative versions of Tables 1-5, in which expected inflation rates are based upon observed rates during the previous 3, rather than 6, years. As a result, this estimate of expected inflation rises more rapidly than that underlying the Tables in the text. Because unanticipated inflation in this calculation is less than thatin the text, the extraordinary realized real gains on equity investment in housing are less. On the other hand, the user cost of capital declines more rapidly so the consumer surplus gains are greater.

Table Al: Inflation Rates (\% per annum)

A. Expected Inflation Rates a/

$\begin{array}{lrrrrrr} & \frac{1964}{1967} & \frac{19670}{1970} & \frac{1973}{1976} & \frac{1979}{6.30} & 6.19 \\ \text { Asset Price (q) } & 0.88 & 2.42 & 4.39 & 3.52 & 8.30 & \\ \text { Rents (p) } & 1.08 & 1.22 & 2.68 & 3.93 & 4.94 & 6.08\end{array}$

a/The data refer to the fourth quarter of the preceding year and are calculated as geometric averages of ex post inflation rate during the previous 12 quarters.

B. Unanticipated Inflation Rates (see a/ above) 
Table A2: Extreordinary Nominal and Real Returns Barned on Investment In Owner-Occupied Housing $(\%)$

Excess Nominal Returns

$\stackrel{\top}{\mathrm{y}}$

(1)

(2)

(3)

0.15

(2) 0.30

1964-69

$1967-72$

$1970-75$

1973-78

$1965-78$

9.72

6.57

4.65

10.79

8.60

11.32

6.59

4.59

17.29

9.24

11.64

6.47

4.47

21.53

9.52

Excess Real

Returns

(4)

0.15

7.20

5.04

3.16

7.07

5.13

(5)

0.30

8.80

5.06

3.10

7.57

5.77

(6)

0.45

9.12

4.94

2.98

7.81

6.05

a/ Based upon rapidly rising expected inflation rates (see Table Al, note $a /$ ).

$\mathrm{b} /$ Hxcess nominal returns less unanticipated general inflation $(\bar{y}-y)$. 
Table A3: Sources of Extraordinary Real Returns, $\quad \tau=0.3(\%)$

\begin{tabular}{|c|c|c|c|c|c|}
\hline & $\underline{62-67}$ & $\underline{64-69}$ & $67-72$ & $70-75$ & $73-78$ \\
\hline Kxcess Ex Post Real Returns & 2.40 & 8.80 & 5.06 & $3 \cdot 10$ & 7.57 \\
\hline $\begin{array}{l}\text { (1) Owing to Mortgage } \\
\text { 2) Owing to Relative Inflation }\end{array}$ & $\begin{array}{l}2.32 \\
0.08\end{array}$ & $\begin{array}{l}7.98 \\
0.82\end{array}$ & $\begin{array}{l}4.48 \\
0.58\end{array}$ & $\begin{array}{l}3.04 \\
0.06\end{array}$ & $\begin{array}{l}6.96 \\
0.61\end{array}$ \\
\hline
\end{tabular}

\section{Memorandum}

(3) Reduction in Ex Post Real Rate if VRM Existed a/

(4) Excess of Unanticipated Housing Inflation over General Inflation b/

$\begin{array}{lllll}0.04 & 0.80 & 1.26 & -0.12 & 1.32 \\ 0.62 & 1.86 & 2.35 & -0.37 & 1.34\end{array}$

a/ Assumes index rate is new issue home mortgage rate.

$\underline{b} / \bar{q}-q-(\bar{y}-y)$

Table A4: User Costs of Capital (\%): Rapidly Rising Expected Inflation Rates

$\frac{1964-4}{N=24} \quad \frac{1972-4}{N=56} \quad \frac{1978-3}{N=24 \quad N=56} \quad \frac{N=24 \quad N=56}{1}$

$\begin{array}{rrrrrrr}T=0.15 & 13.27 & 12.45 & 12.74 & 12.34 & 12.19 & 13.01 \\ T=0.3 & 11.37 & 10.61 & 10.19 & 9.74 & 8.10 & 8.35 \\ T=0.45 & 9.67 & 8.95 & 8.04 & 7.68 & 4.94 & 5.14\end{array}$


Table A5: Combined Annual Real Gains on Owner-Occupied Housing from Anticipated and Unanticipated Inflation (as a Percentage of Equity Invested at the Beginning of the Indicated Period).

\begin{tabular}{|c|c|c|c|c|}
\hline & & $1965-72$ & $1973-78$ & 1979-? \\
\hline & Real Return on Equity Investment & 6.12 & 7.07 & $?$ \\
\hline$\tau=0.15$ & Added Consumer Surplus & $=--$ & 2.08 & 4.15 \\
\hline & TOTAL & 6.12 & 9.15 & $4.15+?$ \\
\hline & Real Return on Equity Investment & 6.93 & $7 \cdot 57$ & 8 \\
\hline$\tau=0.3$ & Added Consumer Surplus & $=--$ & 4.48 & 10.97 \\
\hline & TOTAI & 6.93 & 12.05 & $10.97+?$ \\
\hline & Real Return on Equity Investment & 7.03 & 7.81 & $?$ \\
\hline$\tau=0.45$ & Added Consumer Surplus & $\cdots$ & 5.96 & 13.28 \\
\hline & TOTAL & 7.03 & 13.77 & $13 \cdot 28+?$ \\
\hline
\end{tabular}

a/ Table A2 for $\mathrm{N}=24,1965-72$ data are averages of data for 1964-69 and 1967-72.

b Table A5 for $\mathrm{N}=24$. 